\title{
Nutritional Value of Cucumber Cultivated in Three Selected States of Nigeria
}

\author{
Abbey BW 1 , Nwachoko $\mathrm{N}^{2}$ and Ikiroma $\mathrm{GN}^{3 *}$ \\ ${ }^{1}$ Department of Medical Biochemistry, Rivers State University, Nkpolu-Oroworukwo, Port-Harcourt, Nigeria \\ ${ }^{2}$ Department of Biochemistry, Rivers State University, Nkpolu-Oroworukwo, Port-Harcourt, Nigeria \\ ${ }^{3}$ Department of Chemistry (Biochemistry Option), Rivers State University, Nkpolu-Oroworukwo, Port-Harcourt, Nigeria
}

*Corresponding author: Ikiroma GN, Department of Chemistry (Biochemistry Option), Rivers State University, Nkpolu-Oroworukwo, Port-Harcourt, Nigeria, Tel: +234 903885 8167; E-mail: gifkiromati@yahoo.com

Rec date: August 12, 2017; Acc date: August 22, 2017; Pub date: August 25, 2017

Copyright: (c) 2017 Ikiroma GN. This is an open-access article distributed under the terms of the Creative Commons Attribution License, which permits unrestricted use, distribution, and reproduction in any medium, provided the original author and source are credited.

\begin{abstract}
Cucumber (Cucumis sativus) which was only cultivated in Northern Nigeria in the past, is now cultivated in other parts of Nigeria. However there is no data to show the nutritional quality of cucumber as it relates to the location of cultivation. This research involved the cultivation of cucumber in three selected states of Nigeria, (Rivers, Imo and Plateau State) with the same variety, same technique and treatment. At ten weeks after planting, the cucumber was harvested. The fruit were observed, their quantity, weight and length measured and recorded. The proximate analysis was carried out using standard laboratory technique; mineral analysis $\left(\mathrm{K}^{+}, \mathrm{Na}^{+}, \mathrm{Ca}, \mathrm{Cu}, \mathrm{Mg}, \mathrm{Mn}\right.$ and $\left.\mathrm{Zn}\right)$ was analyzed using the Atomic Absorption spectrophotometer technique.

The result of the physical appearance showed no difference. Also the result of proximate analysis showed that the cucumber cultivated in Plateau State differ significantly at $\mathrm{P}<0.05$ in moisture, protein, crude fiber, ash and fat content when compared with cucumber cultivated in Imo and Rivers States. The result of the mineral analysis showed that cucumber cultivated in Rivers state had the highest value in $\mathrm{Ca}$ and $\mathrm{Mg}$ content and cucumber cultivated in Plateau State had the highest value in $\mathrm{K}^{+}, \mathrm{Cu}, \mathrm{Mn}, \mathrm{Na}^{+}$and $\mathrm{Zn}$ content. The result revealed that cucumber cultivated in Plateau State significantly differ in mineral content. Thus we may say that location is an important factor that could reflect on the nutritional quality of the cucumber.
\end{abstract}

Keywords: Cucumber; Nutritional composition

\section{Introduction}

Cucumber is a creeping vine that bears cylindrical fruits. It is scientifically known as Cucumis sativus it belongs to the gourd family cucubitacea. Other vegetables which belong to this family include Melon, squash, Watermelon and Pumpkins [1]. It originated from the Asia continent [2]. Cucumber plant can be cultivated in both temperate and tropical environment hence it is said to be a native of many regions of the world [3]. There are several varieties of cucumber but the edible cucumber is classified under two groups the slicing and pickling cucumber.

The slicing cucumbers are longer and thinner when compared to the pickling cucumber [4]. Cucumber contains nutrients vital for the body development [5]. It also has several health benefits such as: rehydrating the body, health regulating the blood pressure, body weight management, cholesterol reduction, cancer prevention, bone health, diabetes cure and antioxidant activity [1,6-11]

Cultivation of cucumber requires soil types which possess a high water holding capacity and good drainage. It also requires soil rich in organic matter and manure. The soil $\mathrm{pH}$ ranges from 5.5 to 7.0 [12], its proper development is affected by water logged soil hence it needs a fair amount of water. Planting is usually done on a hill, rows or raised beds. After planting several seed on a hill it is later thinned to 2-3 plant per hill [13]. Harvesting of the cucumber is usually 40 to 60 days after planting [14].
Climates and season differ as you move from the Northern Nigeria to the Southern Nigeria and be broadly classified into two seasons, the dry season and wet season [3]. The environment a plant is cultivated include the soil and the climate of the site of cultivation [15]. The component of soil affects plant growth. The locations of the soil and climate affect the soil composition [16]. Plants which are cultivated in different location will have different quality as a result of the difference in the soil composition and climate [17].

\section{Materials and Methods}

Three States in Nigeria were selected for the study. The states are Rivers, Imo and Plateau. The seeds were bought from fruit garden market, Kaduna Street, Port-Harcourt. Same variety of cucumber was cultivated in the site of choice in the various states. Planting was done on hills. The plants were thinned to two plants per hill. Ten hills were made in each of the farm for the purpose of this study. At the end of ten weeks of planting the cucumber fruits were plucked and collected for analysis.

The physical observation of the yield of the cucumber by measuring the fruit length, weight and counting the number of fruit was done.

The proximate analysis was carried out at the food science laboratory of the Rivers State University Port-Harcourt. It was done using standard laboratory technique as described by Association of Analytical Communities $[18,19]$. The protein analysis was done using the technique described by Chang [20]. The mineral analysis was done using the Atomic Absorption spectrophotometer technique. 
Page 2 of 3

\section{Results and Discussion}

Table 1 showed the result of the physical yield. It showed the number of fruit per plant, weight of fruit per plant and length of fruit. The result reveals that the cucumber from the three states do not differ in physical characteristics.

\begin{tabular}{|l|l|l|l|}
\hline State & $\begin{array}{l}\text { Average number } \\
\text { of fruit Per plant }\end{array}$ & $\begin{array}{l}\text { Average weight of } \\
\text { fruit per plant(kg) }\end{array}$ & $\begin{array}{l}\text { Average length } \\
\text { of fruit(cm) }\end{array}$ \\
\hline Imo & 11 & 2.1 & 21.5 \\
\hline Rivers & 10 & 2.2 & 22 \\
\hline Plateau & 10 & 1.98 & 21.3 \\
\hline
\end{tabular}

Table 1: Yield of plant.

The results of the proximate analysis are shown in Table 2. The moisture content of cucumber from Plateau state was significantly $(\mathrm{p}<0.05)$ low when compared with that of Rivers and Imo state. The protein content range from $0.290 .01 \mathrm{mg} / 100 \mathrm{~g}$ to $0.840 .01 \mathrm{mg} / 100 \mathrm{~g}$. Cucumber cultivated in Rivers state had the least protein content, while the one from Plateau state had the highest protein content. Cucumber cultivated from Imo state had the highest crude fiber content while the one cultivated from Rivers State has the least crude fiber content. For the ash content, Plateau state cucumber showed the highest value of $0.69 \pm 0.00 \mathrm{mg} / 100 \mathrm{~g}$ and Imo state the least $0.42 \pm 0.1$ $\mathrm{mg} / 100 \mathrm{~g}$. This may be due to the low mineral content of Imo state soil [16] and the high mineral content of Plateau state soil [21], since the ash content measures the mineral content of a given sample [18]. The result of fat ranges from $0.30 \pm 0.01 \mathrm{mg} / 100 \mathrm{~g}$ and $0.12 \pm 0.00 \mathrm{mg} / 100$ $\mathrm{g}$, with Plateau State having the highest fat content and Imo state the least fat content. The result on carbohydrate showed that Rivers State cucumber has the highest carbohydrate content $2.63 \pm 0.17 \mathrm{mg} / 100 \mathrm{~g}$ and Imo state the least with $1.89 \pm 0.11 \mathrm{mg} / 100 \mathrm{~g}$.

\begin{tabular}{|l|l|l|l|l|l|l|}
\hline Concentration (mg/100 g) Sample \\
\hline \multirow{2}{*}{ Location } & Moisture & Protein & Crude & Ash & Fat & Carbohydrate \\
\cline { 2 - 7 } & Content & Content & Fiber & Content & Content & Content \\
\hline Rivers & $96.12 \pm 0.06^{* a d}$ & $0.29 \pm 0.01^{*} \mathrm{ad}$ & $0.49 \pm 0.0^{*} \mathrm{bd}$ & $0.42 \pm 0.01^{* \mathrm{bd}}$ & $0.25 \pm 0.00^{* \mathrm{bc}}$ & $2.63 \pm 0.17^{* \mathrm{bc}}$ \\
\hline Imo & $96.21 \pm 0.12^{* \mathrm{ad}}$ & $0.47 \pm 0.01^{* \mathrm{ad}}$ & $0.97 \pm 0.01^{*} \mathrm{ad}$ & $0.35 \pm 0.02^{* \mathrm{ad}}$ & $0.12 \pm 0.001^{* \mathrm{ad}}$ & $1.89 \pm 0.11^{* \mathrm{ad}}$ \\
\hline Plateau & $95.83 \pm 0.18^{* \mathrm{bc}}$ & $0.84 \pm 0.01^{* \mathrm{bc}}$ & $0.60 \pm 0.01^{* \mathrm{bc}}$ & $0.69 \pm 0.00^{* \mathrm{bc}}$ & $0.30 \pm 0.01^{* \mathrm{bc}}$ & $2.41 \pm 0.11^{* \mathrm{bc}}$ \\
\hline
\end{tabular}

Values are expressed as mean \pm standard error of mean (SEM), $n=3$

Value in the same column with different superscripts $(a, b)$, differ significantly at $p<0.05$ when comparing Imo State and other state.

Value in the same column with different superscripts $(c, d)$, differ significantly at $p<0.05$. When comparing Plateau State and other state.

Values the same column with different superscripts $\left(^{*}\right)$, differ significantly at $p<0.05$. When comparing Rivers State and other state

Table 2: Proximate analysis.

\begin{tabular}{|c|c|c|c|c|c|c|c|}
\hline \multicolumn{4}{|c|}{ Concentration $(\mathrm{mg} / 100 \mathrm{~g})$ Sample } & \multirow[b]{2}{*}{ Magnesium } & \multirow[b]{2}{*}{ Manganese } & \multirow[b]{2}{*}{ Sodium } & \multirow[b]{2}{*}{ Zinc } \\
\hline Location & Potassium & Calcium & Copper & & & & \\
\hline Rivers & $145.55 \pm 0.3^{* \mathrm{bd}}$ & $25.47 \pm 0.02^{*} \mathrm{bd}$ & $0.03 \pm 0.00^{*} \mathrm{bd}$ & $15.46 \pm 0.00^{*} \mathrm{bd}$ & $0.08 \pm 0.00^{*} \mathrm{bd}$ & $2.43 \pm 0.00^{*} \mathrm{bd}$ & $0.40 \pm 0.00^{*} \mathrm{bd}$ \\
\hline Imo & $140.01 \pm 0.08^{*} \mathrm{ad}$ & $21.63 \pm 0.00^{*} \mathrm{ad}$ & $0.11 \pm 0.03^{* a c}$ & $14.77 \pm 0.00^{*} \mathrm{ad}$ & $0.27 \pm 0.00^{*} \mathrm{ad}$ & $3.44 \pm 0.03^{*} \mathrm{ad}$ & $0.28 \pm 0.00^{*} \mathrm{ad}$ \\
\hline Plateau & $152.07 \pm 0.06^{*} \mathrm{bc}$ & $20.45 \pm 0.00^{*} \mathrm{bc}$ & $0.14 \pm 0.00^{*} \mathrm{ac}$ & $12.72 \pm 0.01^{\star \mathrm{bc}}$ & $0.81 \pm 0.00^{*} \mathrm{bc}$ & $7.01 \pm 0.00^{*} \mathrm{bc}$ & $0.45 \pm 0.00^{*} \mathrm{bc}$ \\
\hline \multicolumn{8}{|c|}{ Values are expressed as mean \pm standard error of mean (SEM), $n=3$} \\
\hline \multicolumn{8}{|c|}{ Values in the same column with different superscripts $(a, b)$, differ significantly at $p<0.05$. When comparing Imo State and other States. } \\
\hline \multicolumn{8}{|c|}{ Values in the same column with different superscripts $(c, d)$, differ significantly at $p<0.05$. When comparing Plateau State and other State. } \\
\hline \multicolumn{8}{|c|}{ Values in the same column with different superscripts $\left({ }^{*}\right)$, differ significantly at $p<0.05$. When comparing Rivers State and other State. } \\
\hline
\end{tabular}

Table 3: Mineral analysis.

Table 3 showed the result of the mineral content of the cucumber. The result showed that cucumber cultivated in Plateau state had the highest potassium value of $152.07 \pm 0.06 \mathrm{mg} / 100 \mathrm{~g}$ which is significantly high at $\mathrm{p}<0.05$ when compared with the ones of the other two states. This is next to cucumber cultivated in Rivers state and lastly cucumber cultivated in Imo state. The calcium content ranges from $20.45 \pm 0.00 \mathrm{mg} / 100 \mathrm{~g}$ to $25.47 \pm 0.02 \mathrm{mg} / 100 \mathrm{~g}$, with Plateau state having the least value and Rivers state had the highest value. The result on copper showed that cucumber cultivated in Rivers State had the least value of $0.03 \pm 0.00 \mathrm{mg} / 100 \mathrm{~g}$, it also shows that only the copper value of Rivers State differ significantly when comparing cucumber cultivated in Plateau State with Imo and Rivers State. The result on magnesium content shows that Plateau state cucumber had a value $12.72 \pm 0.1 \mathrm{mg} / 100 \mathrm{~g}$ which is significantly low when compared to the other two states. The manganese, sodium, and zinc result showed that Plateau state cucumber had a significantly high content when 
compared to the other two states. The high mineral content could be attributed to the high mineral content of the soil in Plateau state [21]. This corresponds to the findings of Olatunde and Orisoya [17] that the mineral in the soil correlates with the mineral content of the plant grown on it.

\section{Conclusion}

The study showed that the cucumbers cultivated in the three locations do not differ physically. The cucumber cultivated in Plateau State differs significantly from that of Imo and Rivers in the moisture, protein, crude fiber, and ash content. It also differs significantly in potassium, calcium, magnesium, manganese, and zinc content. Hence the location in which the cucumbers are cultivated may affect the nutritional quality. However cucumbers cultivated from the three states have shown from the data obtained to be of good nutritional quality, because the value of the nutritional parameters obtained are within the range of United State standard of cucumber of good quality.

\section{References}

1. Bello MO, Owoeye G, Abdulhammed M, Yekeen TA (2014) Characterization of Gourd fruit (cucubitaceae) for dietary values and anti-nutrition constituent. J Pharm Biol Chem Sci 6: 7575-7585.

2. Abulude OA, Adeleke KO (2010) Comparative studies on nutritional composition of four melon seeds varieties. Pak J Nutr 9: 905-908.

3. Mortimore M (2015) Dry land developers success stories from West Africa environment. J Biol Sci 45: 10-21.

4. Eifediyi EK, Remison SU (2010) Growth and yield of cucumber (Cucumis sativus 1.) as influenced by farm yard manure and inorganic fertilizer. J Plant Breed Crop Sci 2: 216-220.

5. Sunday EK, Hernetta OO (2012) Nutrient composition of common fruits and vegetables in Nigeria. J Biotechnol 45-48.

6. Naganatha S, Hartline R (2015) Cucumber nutritional fact. J Veg Nutr 15 1419-1440.

7. Milder IE, Art IC, Vande PB (2005) Lignan content of dutch plant food, a database including lariciresinol, pinoresinol, secoisolariciresinol, and matairesinol. Br J Nutr 93: 393-402.
8. Rios JL, Recon MC, Escandell JM (2002) Inhibition or transcription factor by plant - derived compounds and their implication in inflammation and cancer. J Pharmacol, California, USA. 15: 1212-1237.

9. Vivian MA (2016) Vitamin $\mathrm{K}$ and bone health. J Global Biosci 5: 1266-1280.

10. Suzanne A (2010) Cucumber and type 2 diabetics.

11. Kumar D, Kumar S, Singh J, Narendre R, Vashistha B, et al. (2010) Free radical scavenging and analgesic activities of Cucumis sativus 1 . fruit. J Young Pharmacist 2: 365-368.

12. Ekwu LG, Utobo GB, Oyesola CA (2007) Vegetative and yield response of cucumber (Cucumis sativus 1.) to staking and nitrogen fertilizer application. J Appl Sci 19: 7509-7519.

13. Ayoola OT, Adeniran ON (2006) Influence of pottery manure and NPK or yield and yield component of crop under different cropping fertilizer systems in South West Nigeria. Afr J Biotechnol 5: 1336-1392.

14. Onyewuchi I (2015) Meet young cucumber farmer who make 2 millon in 2 months. The guardian newspaper.

15. Shao H, Shan Z, Liang Z (1998) Secondary succession and its effect on soil moisture and nutrition in abandoned oil field. J environmental Science 97: 202-215.

16. Onweremadu EU, Osuji GE, Estett ET, Opara CC, Ibeawuchi II (2007) Characterization of soil properties of owner managed farms of Abia and Imo state for sustainable crop production in south eastern Nigeria. J Am Sci 3: $28-37$.

17. Olatunde SE, Onisoya MO (2017) Assessment of heavy metal concentration in pawpaw (Carica papaya Linn) around automobile workshops in Port-harcourt metropolis Rivers state Nigeria. J Heal Pollut 7: 48-61.

18. AOAC (1990) Official Methods of Analysis (15th edn). Association of Official Analytical Chemist, Washington DC, USA.

19. James CS (1995) Experimental procedures for estimation of major food constituent. Chapman and Hall, New York, USA. pp. 71-99.

20. Chang SKC (2003) Protein analysis in food analysis (3rd edn). Khiwer Academic Plenium Publishers New York, USA. pp. 131-142.

21. Ubom GA (1991) The goiter - soil water- diet relationship: Case study in Plateau state Nigeria. Sci Total Environ 107: 1-11. 